Florida International University FIU Digital Commons

2-23-1998

\title{
Pollination and breeding of jackfruit (Artocarpus heterophyllus lam.) in South Florida
}

Sherine El-Sawa

Florida International University

DOI: $10.25148 /$ etd.FI15101281

Follow this and additional works at: https://digitalcommons.fiu.edu/etd

Part of the Biology Commons

\section{Recommended Citation}

El-Sawa, Sherine, "Pollination and breeding of jackfruit (Artocarpus heterophyllus lam.) in South Florida" (1998). FIU Electronic Theses and Dissertations. 3129.

https://digitalcommons.fiu.edu/etd/3129

This work is brought to you for free and open access by the University Graduate School at FIU Digital Commons. It has been accepted for inclusion in FIU Electronic Theses and Dissertations by an authorized administrator of FIU Digital Commons. For more information, please contact dcc@fiu.edu. 
FLORIDA INTERNATIONAL UNIVERSITY

Miami, Florida

POLLINATION AND BREEDING OF JACKFRUIT (Arlocarpus

heterophyllus Lam.) IN SOUTH FLORIDA

A thesis submitted in partial satisfaction of the

requirements for the degree of

MASTER OF SCIENCE

IN

BIOLOGY

by

Sherine El-Sawa

1998 
To: Arthur W. Herriott

College of Arts and Sciences

This thesis, written by Sherine Fawzi El-Sawa, and entitled 'Pollination and Breeding of Jackfruit (Artocarpus heterophyllus Lam.) in South Florida', having been approved in respect to style and intellectual content, is referred to you for judgement.

We have read this thesis and recommend that it be approved.

David Lee

Richard J. Campbell, Co-Major professor

Suzanne Koptur, Major professor

Date of Defense: February 23, 1998.

The thesis of Sherine Fawzi El-Sawa is approved.

Dean Arthur W. Herriott

College of Arts and Sciences

Dr. Richard L. Campbell

Dean of Graduate Studies

Florida International University, 1998 
(C) COPYRIGHT 1998 by Sherine El-Sawa

All rights reserved 
To Essam, mom, dad, mama Zouka and Sue 
I would like to start by thanking God for everything I have.

I wish to lavishly thank Dr. Richard Campbell, my research advisor and committee co-chairman. He patiently and unselfishly provided invaluable academic advice. His confidence in me and encouragement not only made this thesis work possible, but also enhanced my determination to pursue a career in Biology. My gratitude for him is beyond words.

I would like to thank Dr. Suzanne Koptur, chairman of my committee for her guidance and valuable suggestions that helped improve this thesis. I would also like to thank Dr. David Lee for his support. I thank Anne Cox, John Geiger and Hong Liu for their help throughout this work. A special thank you to Suzanne Kennedy, for her priceless feedback and help with my writing style.

My parents, I couldn't have achieved anything in life without them. You're the best! Nothing I say will ever compare to anything you have done for me. My aunt mama Zouka, thanks for encouraging me to go to graduate school and for believing enough for both of us that I can do it. I also thank my sister, Sawsan, for her support and friendship. Finally, my husband, Essam, thank you for being there for me. I wouldn't have started or finished this thesis without your help, support and definitely patience, especially through the tough times. As you always say, this is a step closer to a dream come true. I love you. 


\section{ABSTRACT OF THE THESIS \\ POLLINATION AND BREEDING OF JACKFRUIT (Artocarpus \\ heterophyllus Lam.) IN SOUTH FLORIDA \\ by}

Sherine El-Sawa

Florida International University, 1998

Miami, Florida

Professor Suzanne Koptur, Major Professor

Jackfruit (Artocarpus heterophyllus Lam.) is a multi-purpose fruit tree, native to tropical Asia. It was introduced to South Florida in the early 1900 s but has had little commercial importance. In recent years, there has been an increased interest in jackfruit as a commercial crop in South Florida, but there has been little scientific investigation conducted. The pollination mechanism was not clearly understood. This study focused on jackfruit breeding using 'Dang Rasimi' and 'Cheena' cultivars. Controlled handpollinations revealed that both cultivars were not apomictic. Both cultivars set fruit with self-pollination, but seed set and many fruit characters such as size, flesh percentage and edible percentage were greatly enhanced with cross-pollination. I conclude that jackfruit are outbreeding plants. Tests for pollen dispersal by wind were inconclusive. A variety of insects were collected, but few had a role in pollination. My results suggest that jackfruit are likely to have insect-assisted wind pollination in South Florida. 


\section{TABLE OF CONTENTS}

TOPIC

PAGE

Chapter I: POLLINATION AND BREEDING OF JACKFRUIT

(Artocarpus heterophyllus Lam.) IN SOUTH FLORIDA

Abstract

2

Introduction

3

Materials and Methods

5

Results and Discussion

8

Preliminary Analysis

8

Analysis from 1997

9

Literature Cited

Chapter II: POLLEN VECTORS OF Artocarpus heterophyllus Lam.

IN SOUTH FLORIDA: A PRELIMINARY ANALYSIS

Abstract

Introduction

Materials and Methods

Results and Discussion

Herbivores

Predators

Pollinators

36

Incidental

Pests

Pollen dispersal by wind 


\section{List of Tables}

Table

Table 1. Means \pm standard error of fruit characteristics for the pollination treatments applied to the jackfruit cultivars 'Dang Rasimi' and 'Cheena' in 1997.

Table 2. Means \pm standard error for total weight, flesh weight and flesh percentage of pooled 'Dang Rasimi' and 'Cheena' data.

Table 3. Means \pm standard error of total weight and flesh weight of pooled treatment data for significant cultivar effect.

Table 4. Means \pm standard error of square root of flesh weight and seed number for the pollination treatments applied to 'Dang Rasimi' and 'Cheena'.

Table 5. List of the insects collected from jackfruit trees in South Florida. 


\section{List of Figures}

Figure

Page

Figure 1. Female inflorescence (left) and male inflorescence (right) of jackfruit.

Figure 2. Effect of pollination treatments applied on the average seed number produced by 'Dang Rasimi' and 'Cheena'.

Figure 3. Average seed weight of 'Dang Rasimi' and 'Cheena' following pollination treatments.

Figure 4. Effect of pollination treatments applied on the average edible percentage of 'Dang Rasimi' and 'Cheena'. 
Influence of Controlled Pollination on Jackfruit (Artocarpus

heterophyllus Lam.) Production and Quality 


\title{
Influence of Controlled Pollination on Jackfruit (Artocarpus \\ heterophyllus Lam.) Production and Quality
}

\begin{abstract}
Although jackfruit (Artocarpus heterophyllus Lam.) is an important crop in Asia, and has a commercial potential in South Florida, the breeding system has been overlooked until now. In this study, controlled hand pollinations were used to study the breeding system of jackfruit in South Florida. A 2 X 4 ANOVA in a Randomized Complete Block design was used to test the effect of self-, cross-, and elimination of pollination on total weight, flesh weight, seed weight, seed number, flesh percentage and edible percentage of 'Dang Rasimi' and 'Cheena' jackfruit cultivars. Significant $(\mathrm{P}<0.05)$ cultivar by treatment interactions were found in seed weight, seed number and edible percentage. In addition to the interaction, the treatments differed significantly in total weight, flesh weight and flesh percentage, while the cultivars differed in total weight and flesh weight. Pollination was necessary for fruit set in jackfruit. Both jackfruit cultivars were not highly self-compatible, which may be attributed to self-incompatibility or inbreeding depression. However, 'Dang Rasimi' and 'Cheena' produced good quality fruit when crossed with pollen from another cultivar. The control and the crossed treatments yielded similar results for both 'Dang Rasimi' and 'Cheena' in total weight, flesh weight, seed weight, seed number and edible percentage, indicating that jackfruit are outbreeding plants.
\end{abstract}




\section{Introduction}

Jackfruit (Artocarpus heterophyllus Lam.) is a member of the family Moraceae. The family encompasses about 1000 species in 67 genera, most of which are tropical shrubs, trees and a few herbs. The genus Artocarpus includes about 110 tropical species (Hutchinson 1967).

Jackfruit is monoecious, having male and female flowers on separate inflorescences (Acedo 1992). Individual flowers are borne on an elongated axis forming a racemoid inflorescence, which is termed a spike or head (Acedo 1992), and is enclosed in a protective pair of stipules (Sundararaj and Ramanujam 1953). There are many lightto dark-green male flowers arranged in densely crowded clusters of either sterile or fertile flowers. Female inflorescences are also light- to dark-green in color, but they are larger and have a thicker peduncle than the male inflorescences (Acedo 1992). The surface of

the male inflorescence is smooth, while that of the female is granular (Figure 1). Stigmas are normally short and fresh in appearance for 1 to 2 weeks, but when inflorescences are bagged, the stigmas continue to elongate and remain fresh for a longer period (Primack 1985). Male inflorescences are produced first, and are usually more numerous than females on the trees (Moncur 1985). At anthesis, the male flowers emit a sweet smell often compared to overripe fruit. They typically rot before abscission of the entire male inflorescence (Moncur 1985).

The tree has several uses. Mature fruit are consumed fresh, preserved in a syrup or dried, while unripe fruits are used as vegetables or made into pickles (Singh et al. 
1963). The seeds are roasted and eaten, and have the flavor of chestnuts and the fruit rind and leaves are fed to livestock. The tree itself provides shade for other crops, valuable timber which yields a yellow dye, and latex which is used as a glue to mend earthenware and other utensils (Campbell \& McNaughton 1994; Pursegolve 1968; Singh et al. 1963).

Jackfruit was introduced to South Florida in the early 1900 s, but has had little commercial importance due to cold sensitivity, a limited number of cultivars and its unusual appearance and taste (Campbell \& McNaughton 1994). The recent importation of new cultivars from around the world to South Florida has facilitated the cultivation, survival, and acceptance of jackfruit under South Florida conditions. These cultivars vary in fruit size, fruit weight, seed number, edible percentage, and general morphology of the fruit (Campbell \& McNaughton 1994). Detailed data are lacking on the fruit quality, tree performance and other factors for these cultivars in South Florida. Breeding and selection among these varieties will further enhance the commercial importance of the fruit in the American Tropics.

Jackfruit are reported to be out-breeding plants (Moncur 1985), but there has been no research to demonstrate this. Jackfruit produce many flowers and pollen grains, suggesting they may be outcrossing. Also, not all ovules mature to seed, and anthers are not necessarily adjacent to stigmas, both of which suggest they may not be self-pollinated (Wyatt 1983). Until this study, no data existed as to whether or not jackfruit are selfcompatible or self-incompatible. In many angiosperms self-incompatibility occurs where 
processes impede the normal development of a pollen tube or of fertilization and is the main factor that promotes outbreeding (Endress 1994).

This research focused on the breeding system of jackfruit, and how it influences fruit characteristics. The objectives were to investigate whether jackfruit are outbreeding, self-compatible, or have the ability to set fruit without pollination. Additionally, tests were carried out to determine whether or not there were differences among jackfruit cultivars, and whether or not hand pollination resulted in better fruit set than unassisted or open pollination. Finally, the economic viability of this treatment is considered.

\section{Materials and Methods}

\section{Study Site}

The trees used for this study are maintained as an accessioned plant research collection of the Tropical Fruit Program at Fairchild Tropical Garden Research Center, Miami, Florida. The collection includes fifty trees of twenty-five different cultivars, with twenty-five of the trees blooming during the course of this study. The trees are clonally propagated (grafted) and vary in age from one to ten years. They are irrigated when necessary with microsprinklers and mulched annually with shredded plant material. Insect and disease problems have been minimal and control measures unnecessary. Maintenance is according to commercially accepted protocols for tree fruit production in South Florida. 


\section{Controlled Pollination Experiment}

This experiment was conducted for two fruiting seasons, 1996 and 1997, from January until October of each year. On each tree, four inflorescences were labeled per replicate. One, two or three replicates were applied to a tree depending on tree size and the number of female inflorescences produced. Three treatments and a control were applied. The treatments were: 1) bagged and self-pollinated (selfed);2) bagged and cross-pollinated (crossed); 3) bagged and unpollinated (unpollinated - exclusion of all pollen sources) and 4) control (open pollination). In 1996, 2 replicates of 'Dang Rasimi' were applied on one tree, 1 replicate of 'NS-1' on one tree and 2 replicates of 'Black Gold' on 2 trees. In 1997, due to limitations induced by severe weather conditions, not all of the same cultivars from 1996 were used, however, 4 replicates of 'Dang Rasimi' on 3 trees and 5 replicates of "Cheena" on 3 trees were applied. In both years, 2 trees of the cultivar 'Honey Gold' were used as a pollen source for all the cross-pollinated treatments. The cultivars used as female parents were chosen because of their tendency to produce large numbers of female inflorescences and the availability of more than one tree that had bloomed the previous years.

Paper Pollen-tector (TM) bags (Carpenter Paper Co., Des Moines, Iowa) were placed over the inflorescences, before the inflorescences emerged from the stipules, to ensure no pollen landed on the surface of the flowers prior to treatment. The paper bags were then closed tightly around the peduncle of the inflorescence and tied with a wire label. In 1997, the paper bags were used as described above and additionally secured with parafilm to preclude any space between peduncle and bag that might allow access 
for small insects or pollen. The parafilm kept the peduncles moist and therefore was changed every other day to prevent rotting of the peduncles. For the cross-pollinated treatments, each bag was removed from the inflorescence for about 1 to 2 minutes for hand pollination. The pollen was obtained from the male parents and rubbed in the palm of a sterilized hand, then gently rubbed against the female inflorescences. For the selfpollinated treatments, pollen was obtained from the same trees and applied in the same manner. Hands were washed with $70 \%$ ethyl alcohol between pollinations to prevent contamination between the self- and cross-pollinated treatments and between the different cultivars. Hand pollinations were carried out every other day at mid-morning, beginning from the time the stigmas first appeared on the surface of the inflorescences, until all stigmas disappeared. The bags remained on the inflorescences for two weeks after hand pollinations to prevent any contamination. Bags were then removed and fruit left to develop on the trees until maturity (approximately 160 days). The harvested fruit were evaluated for total weight, flesh weight, seed weight, seed number, flesh percentage and edible percentage. Evaluation was carried out by first measuring total weight of the fruit, then opening the fruit and separating the edible flesh from seeds and unpollinated flowers. The flesh, which is termed 'flakes' or 'bulbs', is made up of meristematic cells of the basal free region of the fruit (Sundararaj and Ramanujam 1953). Each part was then weighed separately and data were recorded. The data were later analyzed $(\mathrm{P}<0.05)$ using a randomized complete block analysis using the SAS program (SAS/STAT Users Guide 1990). Normality tests were conducted on the residuals of all variables using a Shapiro-Wilk test at the $5 \%$ level. Square root transformations were made on the variables that were not normally distributed, and the ANOVA carried out on 
the transformed data. Fisher's LSD Post-hoc test was used to show the differences between the means for all the data.

All seeds collected from the experimental fruit were grown in flat trays using a soil medium of $40 \%$ Canadian peat, $30 \%$ cypress dust, $20 \%$ sand, and $10 \%$ perlite, and were placed in a greenhouse. Seedlings were left to grow until the fourth leaf and then were counted as successfully established seedlings termed "germinated".

\section{Results and Discussion}

\section{Preliminary Analysis}

Preliminary experiments in 1996 indicated that there was a significant cultivar and treatment effect and a significant cultivar by treatment interaction. The most dramatic effect was in the unpollinated treatment, which yielded fruit with seeds in 'Black Gold' and 'NS-1', while the 'Dang Rasimi' had few or no seeds. Also, in 'NS-1', some seeds from selfing and seeds from unpollinated treatments produced albino seedlings. It has been reported that jackfruit occasionally produce bisexual inflorescences (Moncur 1985) which suggested that the seeds produced in the unpollinated treatment may be a product of selfing. However, a study by Sundararaj and Ramanujam (1953) provides evidence that jackfruit produce only unisexual inflorescences. Another study by Jarrett (1976) states that in Artocarpus the compound inflorescences are unisexual, leading us to conclude that the production of seeds in the unpollinated treatment might be either a result of apomixis (asexual reproduction) or contamination either by wind or insects. During this study bisexual inflorescences were 
observed that had predominantly male flowers, yet produced a few rows of female flowers at the base of the inflorescences. The female flowers did not develop, while the male flowers produced anthers and followed normal development. Male flowers were never observed on female inflorescences during this study, and to further investigate this matter, two female inflorescences were used to check for the presence of male flowers among the female flowers. Inflorescences were bagged, in order to insure all stigmas had protruded on the surface, and then collected and placed in $70 \%$ ethyl alcohol. The inflorescences were later inspected and the flowers were counted using a dissecting microscope. Over 7000 female flowers were counted on each inflorescence, and no male flowers were found. Random amplified polymorphic DNA (RAPD) analysis of the albino seedlings revealed that the seedlings from that fruit are not identical, leading us to conclude that the seeds produced in the bagged/unpollinated treatment are a result of sexual reproduction rather than apomixis. To ensure that small pollen vectors were not entering bags through gaps left by twist ties, parafilm was used in the following year.

\section{Analysis from 1997}

In 1997, we found a significant cultivar by treatment interaction $(\mathrm{P}<0.05)$ in seed number, seed weight and edible percentage (Table 1). 'Dang Rasimi' and 'Cheena' also differed in total weight and flesh weight (Table 1). The treatments differed in total weight, flesh weight and flesh percentage (Table 2). From the normality tests conducted on the residuals of the variables using a Shapiro-Wilk test at the $5 \%$ level, two of the variables were not normally distributed; flesh weight $(\mathrm{P}<0.010)$ and seed number $(\mathrm{P}<$ 0.001). Square root transformations were made and the ANOVA carried out on the 
transformed data. Results of the ANOVA on the transformed data were similar to the analysis on the actual (non-transformed) data (Tables 1 and 4); however, there were differences in the Fisher's LSD Post-hoc test in both variables between actual and transformed data. The results of seed number and flesh weight discussed below are based on the ANOVA carried out on the square root transformations.

\section{Total weight}

There was no cultivar by treatment interaction in total weight (Table 1).

However, 'Dang Rasimi' and 'Cheena' were significantly different (Table 3). 'Dang Rasimi' produces significantly bigger fruit than 'Cheena', averaging $5549 \mathrm{~g}$ (Table 3). There was also a significant difference among the treatments (Table 1). The controls and crossed treatments were not significantly different from each other, but were significantly greater than selfed and unpollinated treatments (Table 2). Also, the selfed treatment was significantly different from the unpollinated treatment (Table 2).

\section{Flesh weight}

Flesh weight showed both cultivar and treatment to differ significantly (Table 1). 'Dang Rasimi' and 'Cheena' were significantly different from each other (Table 3). 'Dang Rasimi' produced significantly greater flesh yield than 'Cheena' overall (Table 3). However, that is expected since total fruit weight of 'Dang Rasimi' is greater than that of 'Cheena'. Controls and crossed treatments were not significantly different from each other, but were significantly greater than both selfed and unpollinated treatments (Table 
2). As in the case with total weight, the selfed treatment was significantly greater than the unpollinated treatment, which produced almost no flesh (Table 2).

\section{Sced number}

The number of seeds per fruit showed significant differences in cultivar responses to treatments (Tables 1 and 4). The unpollinated treatment in 'Dang Rasimi' and in 'Cheena' were not significantly different, while the selfed treatment in both cultivars were significantly different (Table 4 and Figure 2). Although the crossed treatment had a greater mean than controls in 'Cheena', the statistical analysis showed that the difference was not significant $(P<0.666)$. On the other hand, in 'Dang Rasimi', although the crossed treatment produced, on average, more seeds than the controls (Figure 2), results of the Post-hoc test show that controls and crossed treatments were not significantly different at $5 \%$ confidence $(\mathrm{P}<0.076)$. However the difference was significant at $7 \%$ confidence. This marginal difference may be attributed to the small sample size, and should not be ignored. Thus, with $93 \%$ confidence hand pollination resulted in more seed production in 'Dang Rasimi'. Depending on the cultivar of jackfruit grown, additional hand pollinations may be recommended to enhance seed production.

\section{Seed weight}

'Dang Rasimi' and 'Cheena' differed significantly in their responses to seed weight (Table 1). Seed weight did not differ in either cultivar between controlled and crossed treatments (Figure 3). Selfed seed in 'Dang Rasimi' did not differ from 'Cheena' controls (Table 1). This may be attributed to the small fruit produced by selfing 'Dang 
Rasimi', and further shows a difference in the behavior of the cultivars. Unpollinated inflorescences gave similar results in both cultivars (Figure 3), which was expected, since 'Cheena' produced no seeds, while 'Dang Rasimi' produced 1 seed, on average, that weighed $8 \mathrm{~g}$. This seed may have been the result of contamination. In addition, the selfed treatment was not significantly different from the unpollinated treatment in 'Cheena', but was significantly different in 'Dang Rasimi' (Table 1 and Figure 3). This is because of the low number of seeds produced by selfed 'Cheena' that were small enough to show a significant difference in seed weight but not in seed number (Tables 1 and 4).

\section{Flesh percentage}

This variable demonstrated the relative amount of edible flesh per fruit. This is of more importance to consumers, especially with such a big fruit. There was no cultivar by treatment interaction effect in flesh percentage (Table 1). Also, the cultivars were not significantly different from one another, while the treatments differed significantly (Table 1). There was no difference between controls and crossed treatments, while both of these treatments differed from the selfed (which had 11\% flesh) and unpollinated (which had $1 \%$ flesh) treatments (Table 2). Also, the selfed treatment was significantly higher than the unpollinated treatment.

\section{Edible percentage}

This variable differs from flesh percentage because it uses both seed weight and flesh weight to estimate the total edible portion of the fruit. Cultivars, treatments and the 
interaction between cultivars and treatments were significantly different (Table 1). There were no significant differences between the control and crossed treatments in either cultivar (Table 1). Unpollinated inflorescences in both cultivars produced very low edible percentages and were significantly different from all other treatments (Figure 4). The selfed treatments differed between the two cultivars, which was expected as 'Dang Rasimi' has bigger fruits and is more likely to produce more edible portions of the fruit depending on the treatment. With respect to seed germination, neither factor (cultivar, treatment) nor their interaction were significantly different.

\section{Breeding system}

While Sundararaj and Ramanujam (1953) stated that parthenocarpic development of jackfruit is not known, Moncur (1985) stated that parthenocarpic development of jackfruit is unlikely. Based on the cultivars used in this study, it was found that jackfruit do not set fruit without pollination. The variables total weight, flesh weight, seed weight, seed number, flesh percentage and edible percentage all support this conclusion. Thus, this study has demonstrated that jackfruit are not parthenocarpic.

Hand pollination using crossed pollen resulted in similar quality fruits to those that were open-pollinated. In the variables total weight, flesh weight and flesh percentage, where there was no cultivar by treatment interaction, control and crossed treatments not significantly different (Table 2). Additionally, with seed weight and edible percentage where there was an interaction effect, in both cultivars, the control and crossed treatments were not different (Table 1). Also, the selfed treatments produced 
significantly lower yields than the open and cross-pollinated treatments. This leads us to conclude that the open-pollinated jackfruit are outbreeding.

The poor quality fruits produced by the selfed treatments may be a result of either self-incompatibility or inbreeding depression. Self-incompatibility is often not absolute and various levels of incompatibility may occur (Endress 1994). The proportion of seed and fruit set after self-pollination may indicate the degree of self-incompatibility, Zapata and Arroyo (1978) used an index of self-incompatibility (ISI), calculated by dividing the average number of seed set per self-pollination by the same following cross-pollination. Using this measure, self-compatible species score 1 , incompletely compatible score $0.2-$ 1 , and self-incompatible score $<0.2$. Using average seed number produced from selfversus cross-pollinated jackfruit, the ISI was 0.15 for 'Dang Rasimi' and 0.14 for 'Cheena', which categorizes them as self-incompatible (Zapata and Arroyo 1978). On the other hand, self-pollination of predominantly outcrossing self-compatible species generally results in inbreeding depression (Endress 1994). Inbreeding depression, as a rule, is low in partially inbreeding populations, while it has high values in outbreeding plants (Charlesworth and Charlesworth 1987). Cumulative inbreeding depression was calculated for seed number as $\delta=1-w_{s} / w_{o}$, where $w_{s} / w_{0}$ (cumulative relative fitness) is the product of the mean relative fitness for seed number (Husband and Schemske 1996). Inbreeding depression was 0.85 for 'Dang Rasimi' and 0.86 for 'Cheena'. For naturally selfing species, one certainly might not expect to find much evidence for inbrecding depression if the results of selfing are compared with those of crossing (Charlesorth and Charlesworth 1987). In the case of jackfruit, however, since they are outcrossing, it is 
expected that inbreeding depression is high. In spite of that, the presence of a physiological incompatibility in jackfruit may lead to an overestimate of early inbreeding depression, particularly since the relative seed production upon selfing was extremely low (Husband and Schemske 1996). Additionally, Charlesworth and Charlesworth (1987) stated that it is often difficult to tell whether self-incompatibility or late-acting inbreeding depression is involved. This may be the case in jackfruit, since jack fruit had very low fertility, as indicated by the seed number, from selfing compared with crossing. This was not a complete study of the specific aspects of self-incompatibility and inbreeding depression; however, based on these data, the poor fruit resulting from selfpollination of jackfruit may be attributed to one of these two phenomena. In either case, we recommend interplanting of jackfruit cultivars to ensure better fruit set.

There is substantial variation between jackfruit cultivars. 'Dang Rasimi' produced bigger fruit than 'Cheena', and showed significantly higher total weight, flesh weight, seed number and seed weight. While the effect of hand pollination was not significant in 'Cheena', the difference was marginally significant $(P<0.076)$ in seed number of 'Dang Rasimi', and therefore hand pollination may improve seed production depending on the cultivar used.

Based on the cultivars used in this study, jackfruit are outbreeding plants. They do not have the ability to set fruit without pollination and therefore are not apomictic. Self pollination was less successful in both 'Dang Rasimi' and 'Cheena' which may be because of either self-incompatibility or inbreeding depression; therefore, interplanting of 
cultivars is recommended to ensure better fruit set. In addition, hand pollination may result in better fruit set of 'Dang Rasimi'. Due to the differences found in the cultivars used for this study, these conclusions cannot be extended to other jackfruit cultivars and future studies are needed to test and evaluate the performance of other cultivars in order to determine their effects. 


\section{Literature Cited:}

Acedo, AL (1992). Jackfruit biology, production, use, and Philippine research.

Forestry/Fuelwood Research and Development (F/FRED), Arlington, VA.

Campbell, RJ, McNaughton, R (1994). New jackfruit cultivars under trial in South

Florida. Proc. Interamer. Soc. Trop. Hort. 38: 201-205.

Charlesworth, D and Charlesworth B (1987). Inbreeding depression and its evolutionary consequences. Ann. Rev. Ecol. Syst. 18: 237-68.

Endress, PK (1994). Diversity and evolutionary biology of tropical flowers. Cambridge University Press, Cambridge.

Husband, BC and Schemske, DW (1996). Evolution of the magnitude and timing of inbreeding depression in plants. Evolution 50(1): 54-70.

Hutchinson, J (1967). The genera of flowering plants. Oxford University Press, Ely House, London W.I.

Moncur, MW (1985). Floral ontogeny of the jackfruit. Australian Journal of Botany 33: $585-93$.

Primack RB (1985). Comparative studies of fruits in wild and cultivated trees of champedak (Artocarpus integer) and terap (Artocarpus odoratissimus) in Sarawak, East Malaysia with additional information on the reproductive biology of the Moraceae in Southeast Asia. Malay. Nat, J. 39: 1-39.

Purseglove, JW (1968). Tropical Crops - Dicotyledons. Longman Scientific \& Technical, Essex, England. 384-386.

Samaddar, HN (1985). Jackfruit. In Bose, TK Fruits of India: Tropical and subtropical. Calcutta: Naya Prokash, 487-497. 
SAS/STAT Users Guide (1990). SAS Institute Inc. SAS Campus Drive.

Singh, S, Krishnamurthi, S, Katyal, SL (1963). Fruit culture in India. Indian Council of Agricultural Research, New Delhi, 233-236.

Sundararaj, DD and Ramanujam, K. (1953). Studies on the floral morphology of jack Artocarpus heterophyllus Lamk. (Syn. A. integrifolius, L.f.) S. Indian Hortic. $1,56-61$.

Wyatt, R (1983). Pollinator-plant interactions and the evolution of breeding systems, 5195. In Real, ed. Pollination Biology. Academic Press Inc., Orlando.

Zapata, TR and Arroyo, MTK (1978). Plant reproductive ecology of a secondary deciduous tropical forest in Venezuela. Biotropica 10(3): 221-230. 


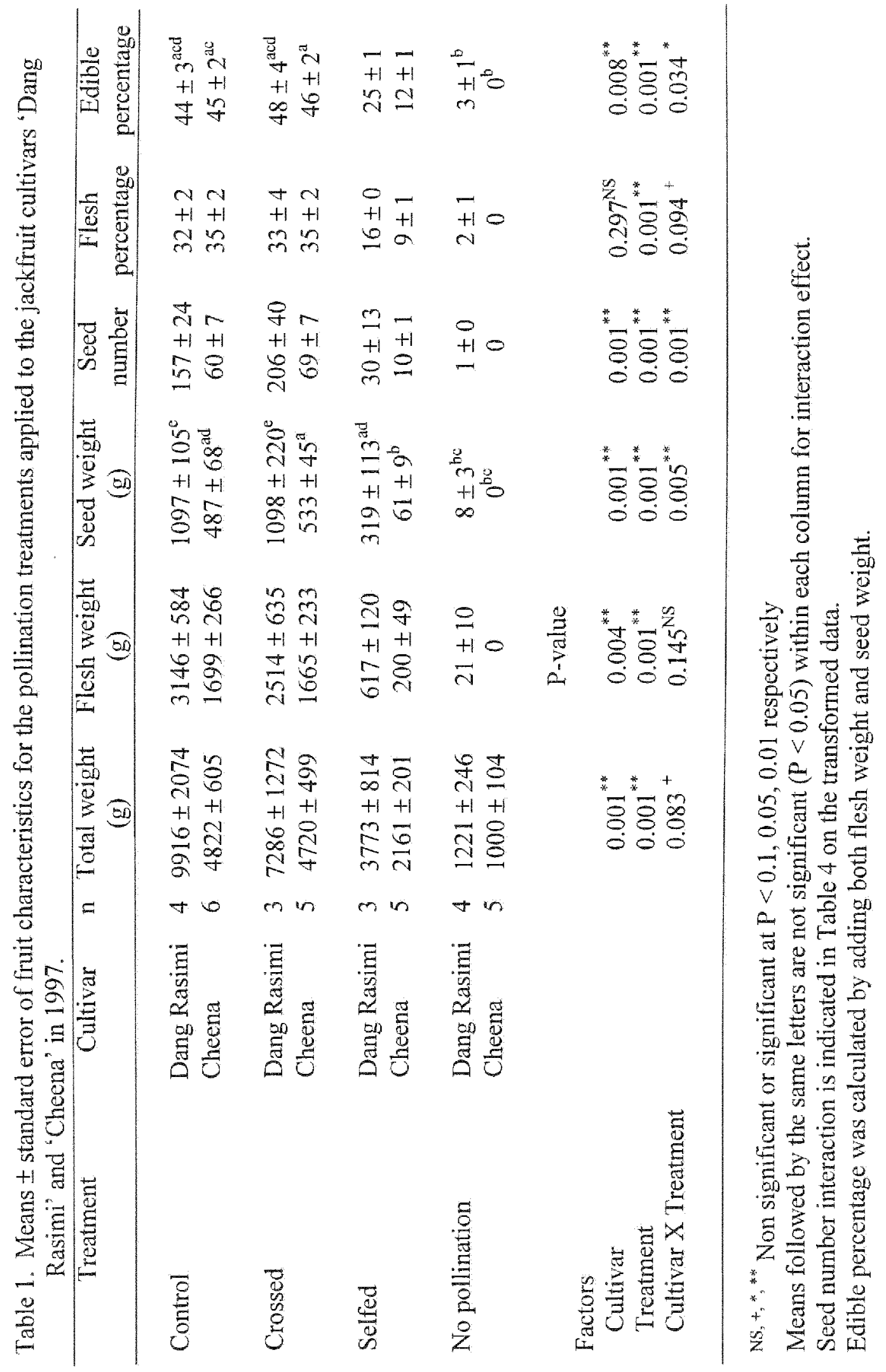




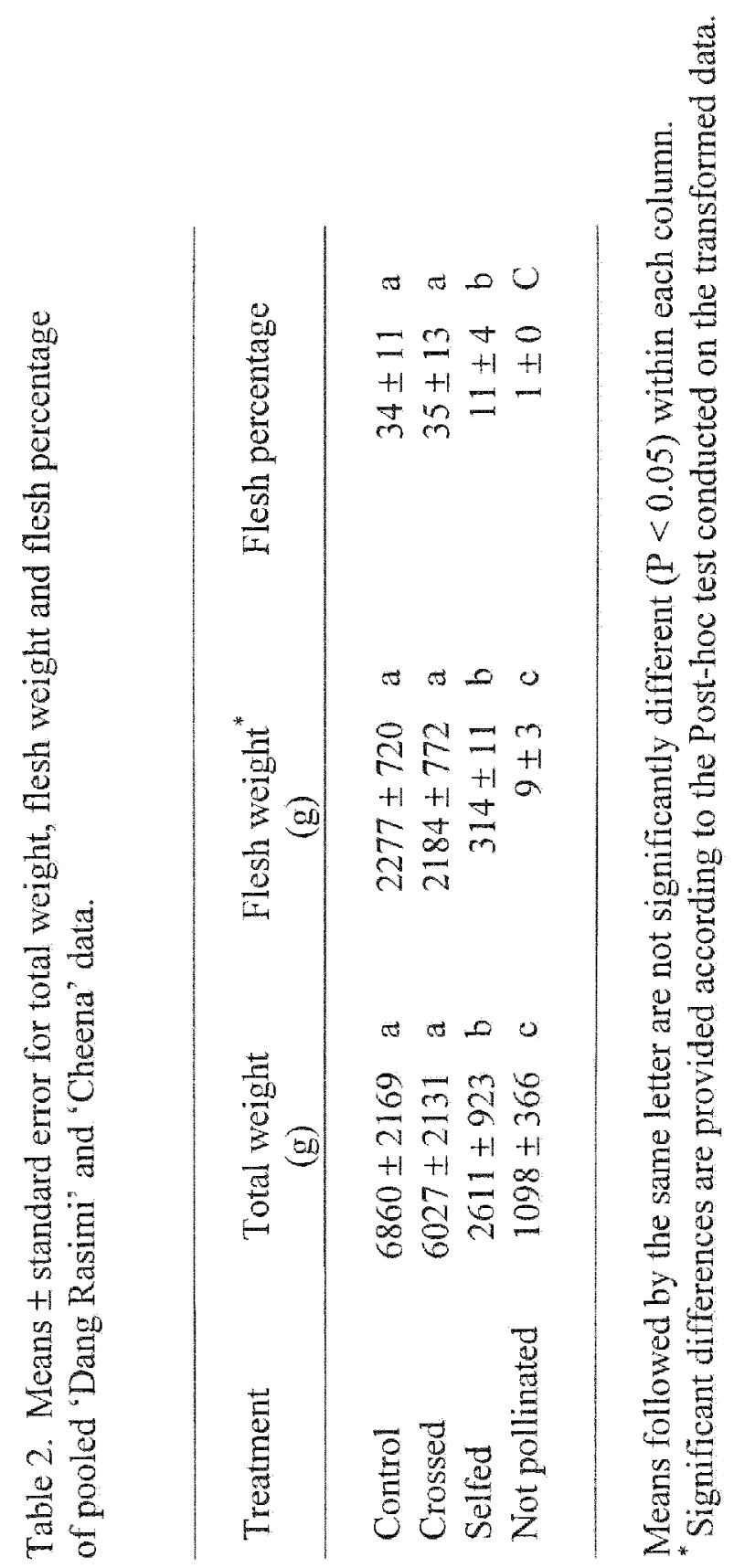


Table 3. Means \pm standard error of total weight and flesh weight of pooled treatment data for significant cultivar effect.

\begin{tabular}{lcccc}
\hline Cultivar & $\begin{array}{c}\text { Total weight } \\
(\mathrm{g})\end{array}$ & & $\begin{array}{c}\text { Flesh weight } \\
\text { (g) }\end{array}$ & \\
\hline Dang Rasimi & & & & \\
Cheena & $5549 \pm 957$ & a & $1575 \pm 373$ & a \\
& $3176 \pm 476$ & b & $891 \pm 229$ & b \\
\hline
\end{tabular}

Means followed by the same letter are not significantly different $(P<0.05)$ within each column.

* Significant differences are provided according to the Post-hoc test conducted on the transformed data. 
Table 4. Means \pm standard error of square root of flesh weight and seed number for the pollination treatments applied to 'Dang Rasimi' and 'Cheena'

\begin{tabular}{|c|c|c|c|}
\hline Treatment & Cultivar & Flesh weight (g) & Seed number \\
\hline Control & $\begin{array}{l}\text { Dang Rasimi } \\
\text { Cheena }\end{array}$ & $\begin{array}{l}55.28 \pm 5.49 \\
40.57 \pm 3.24\end{array}$ & $\begin{array}{r}12 \pm 1 \\
8 \pm 0\end{array}$ \\
\hline Crossed & $\begin{array}{l}\text { Dang Rasimi } \\
\text { Cheena }\end{array}$ & $\begin{array}{l}49.18 \pm 6.93 \\
40.41 \pm 2.93\end{array}$ & $\begin{array}{r}14 \pm 1 \\
8 \pm 0\end{array}$ \\
\hline Selfed & $\begin{array}{l}\text { Dang Rasimi } \\
\text { Cheena }\end{array}$ & $\begin{array}{l}24.61 \pm 2.33 \\
13.76 \pm 1.65\end{array}$ & $\begin{array}{ll}5 \pm 1 & \text { d } \\
3 \pm 0 & \text { e }\end{array}$ \\
\hline Unpollinated & $\begin{array}{l}\text { Dang Rasimi } \\
\text { Cheena }\end{array}$ & $\begin{array}{c}3.77 \pm 1.46 \\
0\end{array}$ & $\begin{array}{rr}1 \pm 0 & b \\
0 & b\end{array}$ \\
\hline $\begin{array}{l}\text { Factors } \\
\text { Cultivar } \\
\text { Treatment } \\
\text { Cultivar X treatment }\end{array}$ & & $\begin{array}{l}\text { P-value } \\
0.001^{* *} \\
0.001^{* *} \\
0.454^{\mathrm{NS}}\end{array}$ & $\begin{array}{l}0.001^{* *} \\
0.001^{* *} \\
0.002^{* *}\end{array}$ \\
\hline
\end{tabular}

$\mathrm{NS},+, *,{ }^{* *}$ Non significant or significant at $\mathrm{P}<0.1,0.05,0.01$ respectively Means followed by the same letters are not significant $(\mathrm{P}<0.05)$ within each column for interaction effect. 


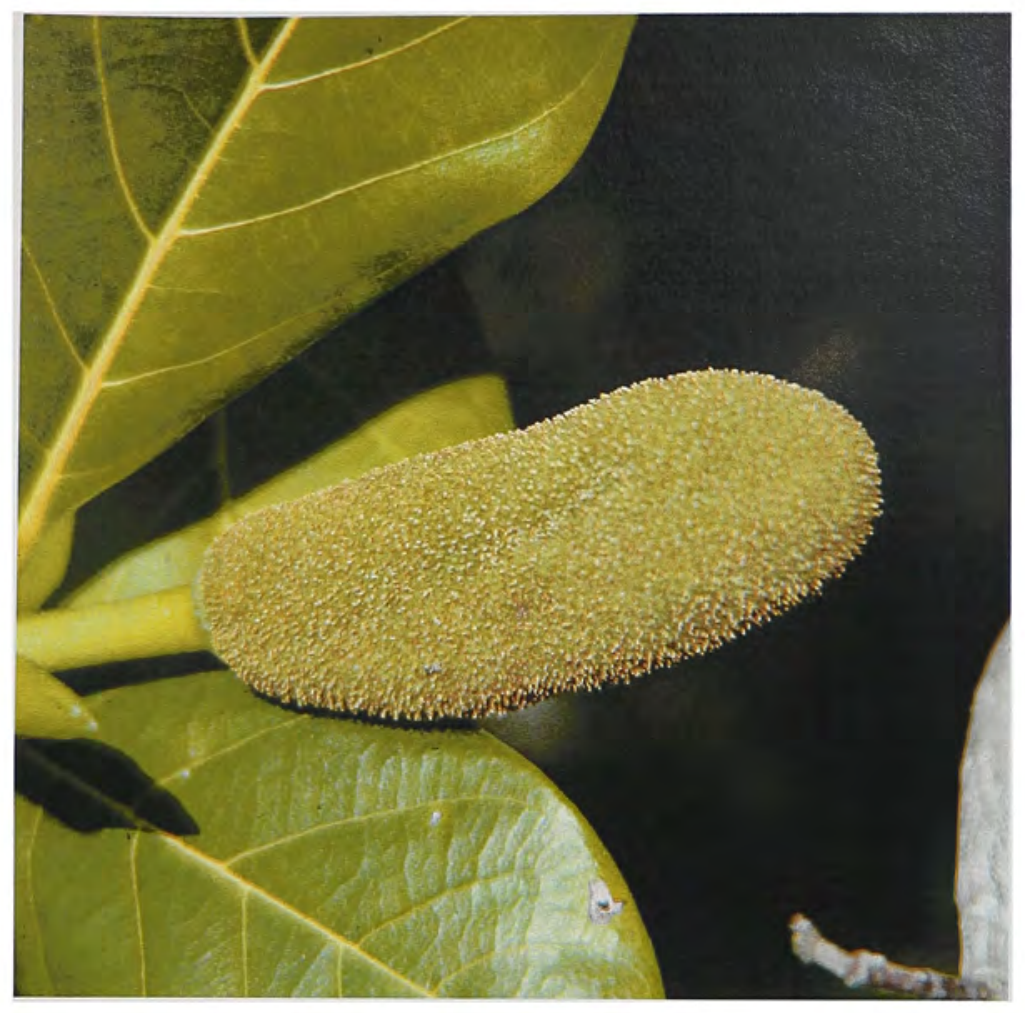

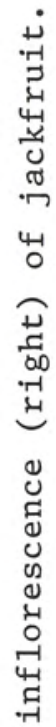

굽

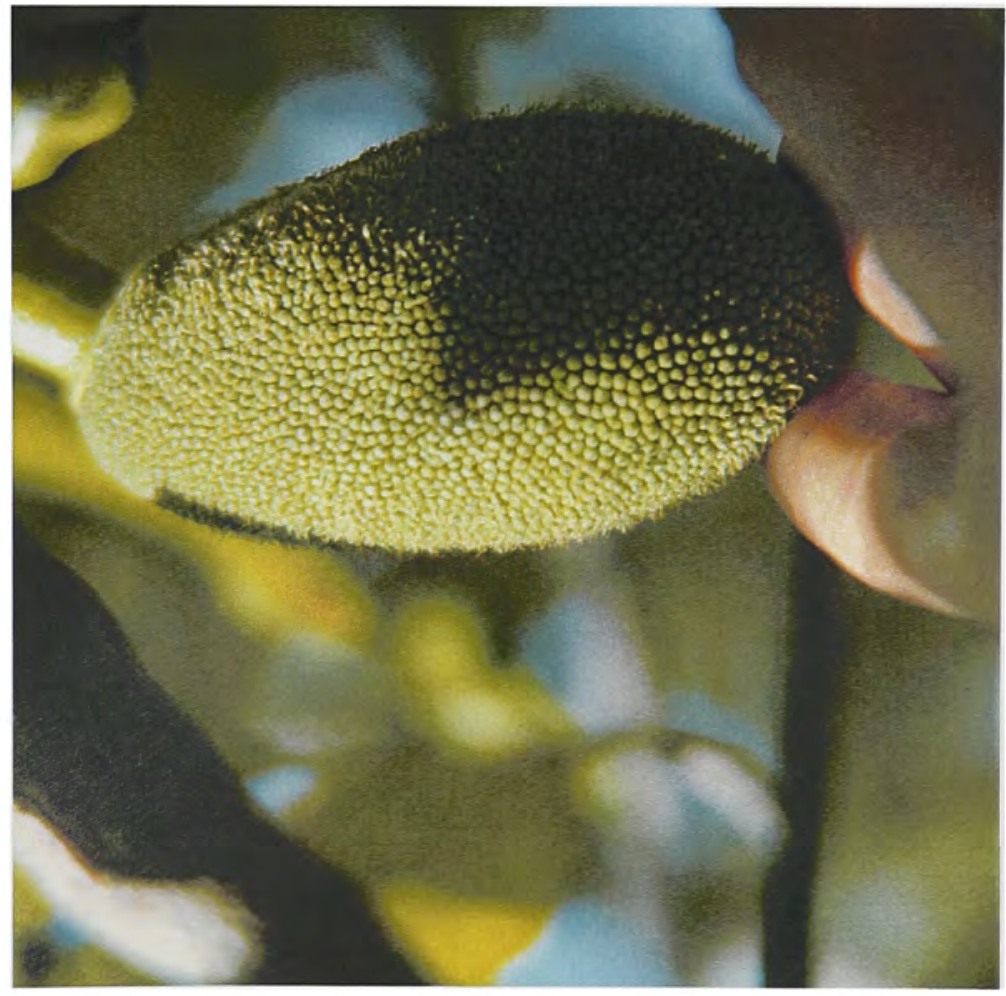

ت్ర

蒈

Uే

$-$

劲 


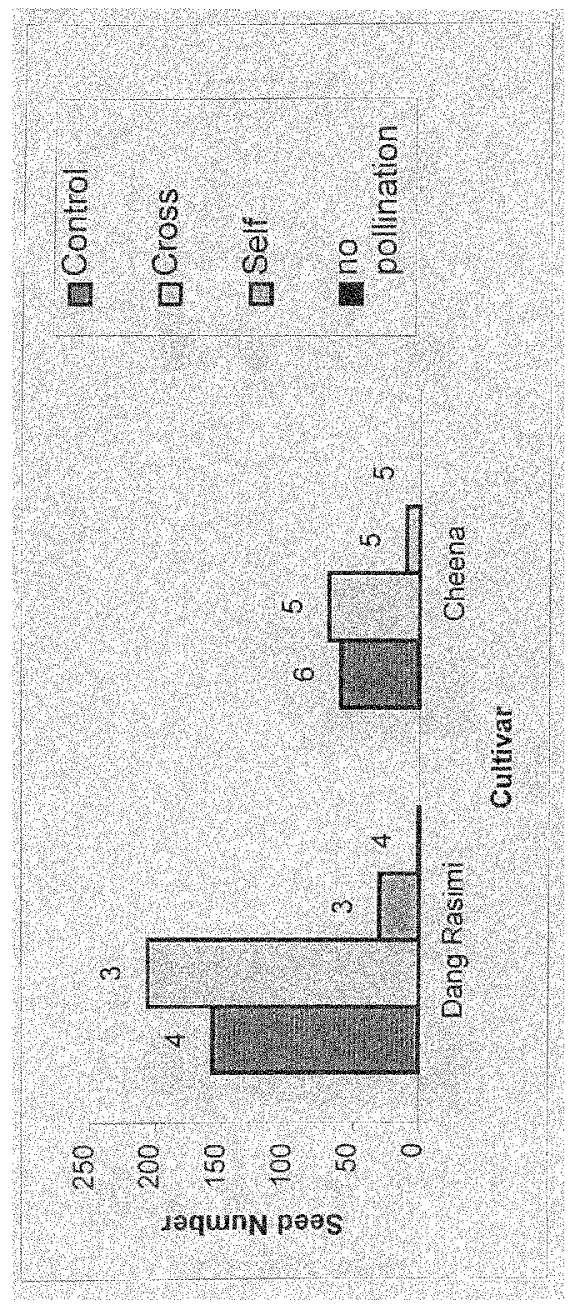

.

อี

定

总

莺

D

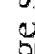

ธี

$\sum$

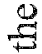

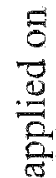

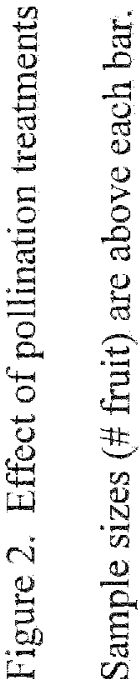




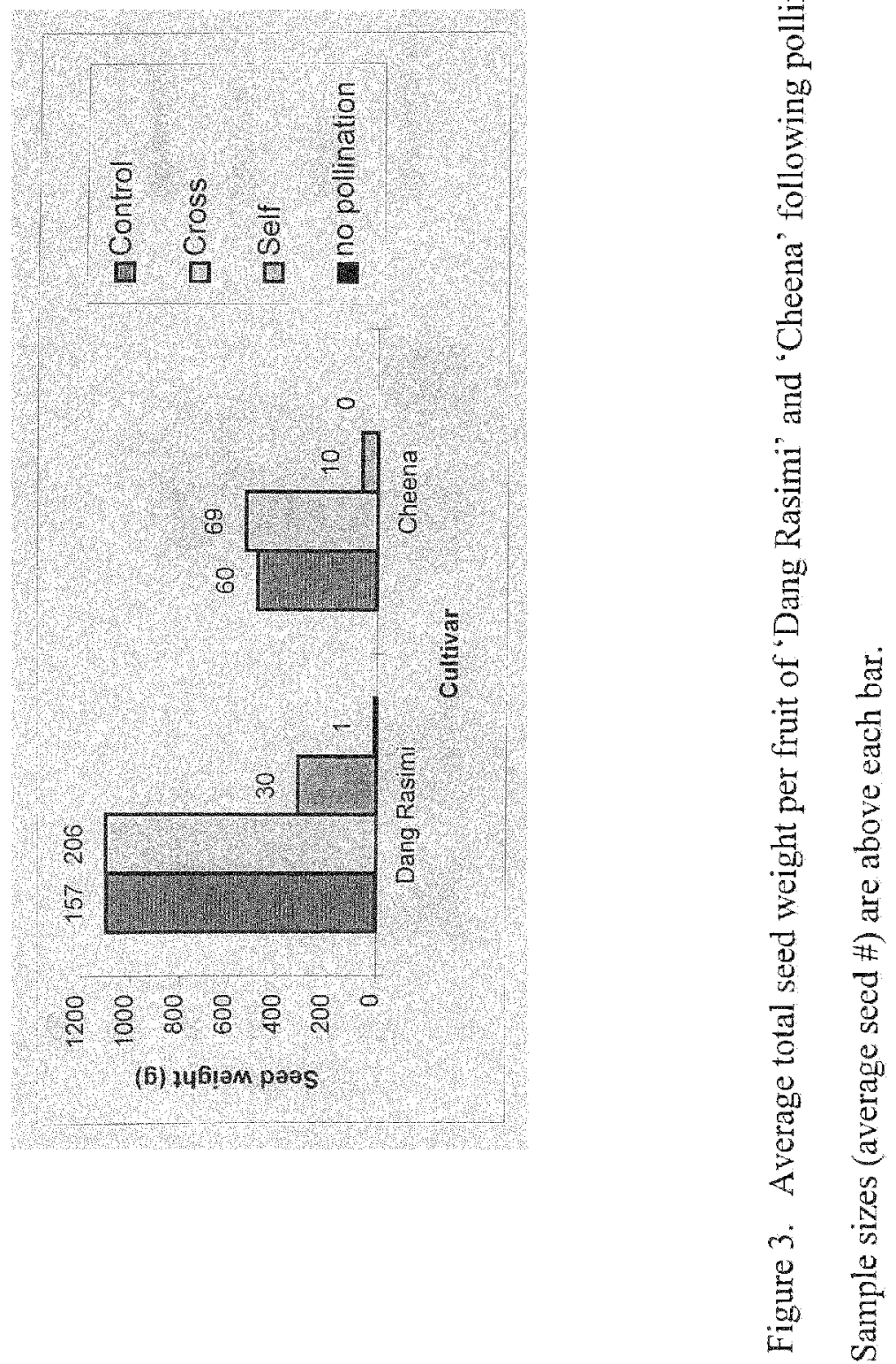



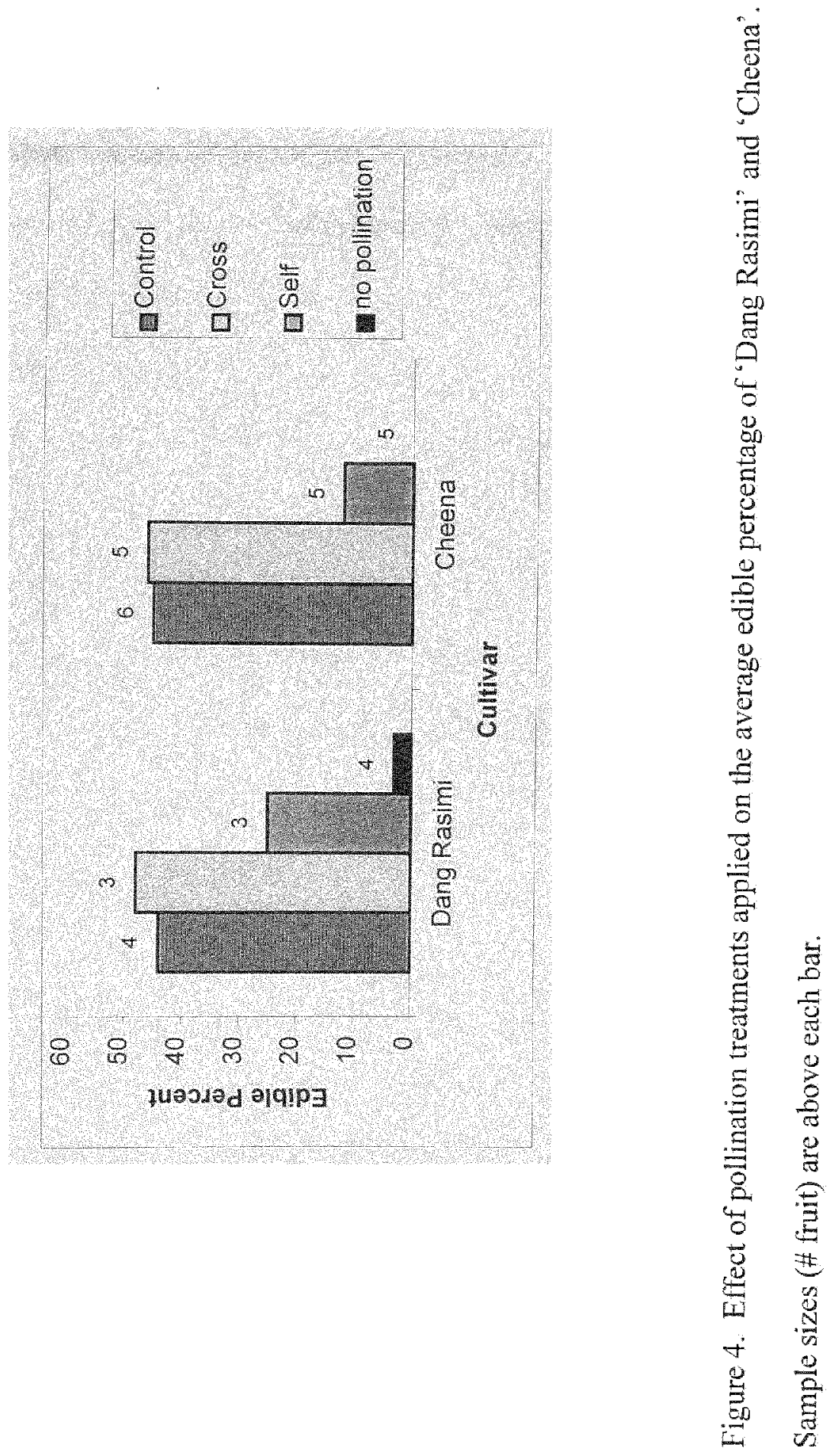
Pollen Vectors of Artocarpus heterophyllus Lam. In South Florida: A Preliminary Analysis 


\title{
Pollen Vectors of Artocarpus heterophyllus Lam. In South Florida: A \\ Preliminary Analysis
}

\begin{abstract}
Jackfruit (Artocarpus heterophyllus Lam.) is native to tropical Asia where it has significant commercial importance. It was introduced to South Florida in the early 1900s but has had little commercial importance in the United States. In recent years, there has been increased commercial interest in this crop in South Florida, but little scientific investigation has been conducted. Jackfruit pollination is not clearly understood. It has been suggested that pollination is by wind, by insects, and by both wind and insects. A study was designed to test the occurrence of the different pollination mechanisms. Tests for pollen dispersal by wind were inconclusive. A variety of insects were collected and their potential role discussed; however, few were associated with pollination. Results suggest that jackfruit are likely to have insect-assisted wind pollination in South Florida.
\end{abstract}

\section{Introduction}

Jackfruit (Artocarpus heterophyllus Lam.) is native to Tropical Asia. It occurs in the rainforests of the Western Ghats of South India (Soepadmo 1991). Jackfruit is cultivated in Southeast Asia, Malaysia, the Philippines, Mauritius, and East Africa (Morton 1990). In India, only banana and mango exceed the jackfruit in volume of local consumption (Morton 1990). The fruit vary from 1 to over $50 \mathrm{~kg}$ depending on the cultivar (Moncur 1985) and are consumed in many ways. The pulp is cooked as a vegetable, pickled or canned. The pulp of ripe fruit is eaten fresh, made into delicacies, 
chutney, jam, jelly, paste or preserved as candies by drying or mixing with sugar, honey or syrup. In addition, the pulp is also used as a flavor for ice cream and beverages (Soepadmo 1991). The seeds can be boiled or roasted and have the flavor of chestnuts (Campbell and McNaughton 1994). The tree itself is known for its timber, which is classified as a medium hardwood (Soepadmo 1991). In addition, the jackfruit tree is renowned for its medicinal properties (Soepadmo 1991). The pulp and seeds are considered a cooling and nutritious tonic and are used in China to overcome effects of alcohol. In Southeast Asia, seed starch is used to relieve biliousness and roasted seeds are regarded as an aphrodisiac. Heated leaves are placed on wounds and latex (when mixed with vinegar) promotes healing of abscesses, snakebites and glandular swellings. The wood has sedative properties and its pith is said to induce abortion. The root is also used as a remedy against skin diseases and asthma and its extract is taken in cases of fever and diarrhea (Soepadmo 1991).

Despite the importance of jackfruit, especially in Southeast Asia, few statistics are available. In 1987, there were 40,700 ha of jackfruit in Thailand producing 56.5 million fruits, 1500 ha in Malaysia producing 13,000 tons of jackfruit (Soepadmo 1991), while in the Philippines there were 12,970 ha producing 67,527 tons of jackfruit (CRC 1990). In India, there were an estimated 26,000 ha of jackfruit (Butani 1979). Jackfruit has had little commercial value in South Florida because of its cold sensitivity, unusual fruit odor and flavor, and the unavailability of superior selections. 
Jackfruit trees are monoecious, bearing male and female inflorescences on the same tree (Acedo 1992). The flowers are borne on an elongated axis forming a racemoid inflorescence known as 'spike' (Acedo 1992) and are enclosed in a pair of protective stipules (Sundararaj and Ramanujam 1953). Male inflorescences are borne on short shoots on main and lateral branches, while the female inflorescences are found only on the trunk and main branches. The female inflorescences differ from the males in being larger and having a thicker peduncle (Acedo 1992). Male inflorescences are produced first and usually more males develop than females on the trees (Moncur 1985). At anthesis, the male flowers emit a sweet aroma of overripe fruit. The inflorescence eventually rots before abscission (Moncur 1985). A species that is very similar to jackfruit is Artocarpus integer (Thunb.) Merr. commonly known as chempedak (Primack 1985). The two species are similar in structure; however, jackfruit has a larger subglobose female inflorescence and fruit, a green annulus at the top of the female inflorescence, and glabrous leaves (Primack 1985).

The mechanism of jackfruit pollination is not well understood, although pollination has been reported essential for fruit set (Acedo 1992; Sundararaj and Ramanujam 1953). Controlled hand pollination experiments have revealed that jackfruit are not parthenocarpic, some jackfruit cultivars are highly self-incompatible, and crossed hand pollination treatments produced fully developed fruits (S. El-Sawa, unpublished data). Understanding pollination will contribute to agricultural development of the tree under the conditions of Tropical America and will permit increased production and yield. It will also help in the development of new cultivars. Jackfruit has been described as a 
wind-pollinated species (Samaddar 1985). Other Artocarpus flowers are pollinated apparently by unspecialized insects and wind (Primack 1985). The production of more male than female flowers is a characteristic typical of wind pollinated species. However, pollen is sticky and not shed readily by light physical disturbance as would be expected from a wind-pollinated tree (Acedo 1992; Moncur 1985). Jackfruit has also been described as an insect-pollinated species (Purseglove 1968). Although some pollinating insects are attracted to the male inflorescence because of their sweet scent, none have been reported to visit the female inflorescences. While pollination solely by wind or insects seems unlikely, an alternative mechanism may involve both insects and wind (Moncur 1985). Insect activity on the male inflorescence may promote the release of pollen, which may then be carried by wind. Such behavior may be an evolutionary transition between insect and wind pollination (Acedo 1992).

Some members of the family Moraceae, such as Ficus, represent a major contrast in their reproductive ecology to the genus Artocarpus (Primack 1985). Species of Ficus are pollinated by specialized wasps, which are completely dependent on Ficus for the completion of their life cycle. Figs have unisexual urceolate inflorescences and unlike jackfruit, figs produce more female than male flowers (Endress 1994). However, Proctor et al. (1996) state that breeding of pollinating flies takes place in the male inflorescences of jackfruit. They state that small bees and 2 genera of Diptera pollinate this species, and after flowering, when the male inflorescences drop, the pollinating flies breed in them. Moncur (1985) has observed vinegar flies (D. immigrans) on the rotting male inflorescences, however he reported never seeing them on the female inflorescences. 
Previous studies in countries where jackfruit grow extensively were contradictory in the mode of pollination, and some were inconclusive. Some of these studies suggested that jackfruit are wind-pollinated, and some suggested jackfruit are insect-pollinated. The primary objective of this study was to collect and identify insects associated with jackfruit in order to determine their potential role in pollination. As a second objective, pollen transfer by wind was also tested.

\section{Materials and Methods}

The jackfruit collection of the Tropical Fruit Program at Fairchild Tropical Garden Research Center in Miami, Florida was used for this study. There are fifty trees of twenty-five different cultivars, with twenty-five of the trees blooming. The trees are clonally propagated by grafting and vary in age from one to ten years. They are irrigated when necessary using microsprinklers and mulched annually with shredded plant material. Insect and disease problems have been minimal and no control measures have been necessary. The trees are maintained according to commercially accepted protocols for tree fruit production in South Florida.

\section{Pollinator observations}

Trees were observed for 1 to 2 hours at different times during the day (daylight) for a total of approximately 200 hours, and 3 to 4 hours at different times during the night (dark) for a total of approximately 24 hours. A battery-powered flashlight was used with

a red filter to observe inflorescences in the dark. Daytime observations were made 2 to 3 
times per week from January through October 1996, and again in 1997. Nighttime observations were made 1 to 2 times/week for 2 months during the peak of bloom, in April and May 1997. Observations were made at 20-minute intervals (15 minutes out of every 20 minutes were spent watching).

Destructive sampling was carried out using both male and female inflorescences several times during the day and during the night. Three female inflorescences were used during the day and 3 during the night, and 9 male inflorescences were used during the day and 3 during the night. Flowers used for destruction were at different stages of floral development, while those used for pollinator observation were in full bloom.

In addition to observation of male and female inflorescences for pollinators, random trees were examined for the presence of other insects using a $10 \mathrm{x}$-hand lens when necessary. Insects found were collected and sent to the Florida Department of Agriculture and Consumer Services / Division of Plant Industry for identification. Insects mentioned in this paper are those that were observed more than once on the trees.

\section{Wind-borne Pollen Trapping}

A pollen trap made of flat, sticky surface to which pollen adheres is a basic method used in many studies to determine if pollen is being carried by wind (Kearns and Inouye 1993). A total of thirty microscope slides were coated with petroleum jelly and hung within the trees at three different heights $(1,1.5$ and $2 \mathrm{~m})$ from the ground, during dry weather between April and September 1997. Three slides were placed in a tree on 
different days. Slides were placed within 2 to $3 \mathrm{~cm}$ of either a staminate or pistillate inflorescence, left for 24 hours, and then collected and examined for presence of pollen grains using a compound microscope. In addition to the above mentioned, 9 slides were placed during rainy days; these were later excluded from the experiment because heavy rain washed the petroleum jelly from the slides. Captured pollen grains were compared with prepared reference slides of jackfruit pollen grains.

\section{Results and Discussion}

Thirteen insect species were found associated with jackfruit. There were 3 herbivores, 1 potential pollinator, 1 predator, 2 incidental and 6 were potential pests (Table 5). Each group will be presented and discussed separately.

\section{Herbivores}

Automeris io (F.) (Lepidoptera: Saturniidae), the Io moth, was collected from jackfruit trees. The larva was feeding on the leaves. A mature larva reaches a length of about $50 \mathrm{~mm}$ (Chellman 1978). Larvae are greenish with a red upper stripe and white lower stripe on each side. Larvae are known to feed on rose, willow, ixora, oak and other trees in Florida (Maxwell 1990). They also have been reported to feed on acacia, orchid tree, seagrape, seaside mahoe, tree hibiscus and tree of gold (Chellman 1978).

Occasionally, populations are sufficient to cause noticeable defoliation, however, natural enemies usually keep the number low (Chellman 1978). 
Megalopyge opercularis (J.E. Smith) (Lepidoptera: Megalopygidae), the Puss caterpillar, was also collected from jackfruit trees. This caterpillar is the most poisonous of Florida's stinging caterpillars (Maxwell 1990). The body of the larva is rather flat and covered with silky hair that is tawny to white in color (Maxwell 1990). The larvae are known to feed on orange, pecan, almond, brazilian pepper, persimmon and moonflower vine (Kimball 1965). They are also known to feed on oak and citrus among other trees (Maxwell 1990).

Sibine stimulea (Clemens) (Lepidoptera: Limacodidae), the Saddleback caterpillar, was collected from the leaves. Both ends of this caterpillar larva are brownish with fleshy tubercles on them. The central section is light green and is like a saddle blanket with a brown saddle placed in the middle of it. Both ends and the sides are armed with nettling hairs that are connected to poison glands (Maxwell 1990). They are known to feed on areca palm, rose, willow, corn, castor bean and many other shrubs (Maxwell 1990) and have been reported to feed on corn and citrus (Kimball 1965).

These three herbivores were collected during the day. They have not caused any serious damage to the jackfruit trees. While population densities of each are low and do not appear to be damaging the jackfruit trees, it is important that such associations be documented. These herbivores do not appear to cause a threat to jackfruit production in South Florida at present. 


\section{Predators}

Zelus longipes (L.) (Hemiptera: Reduviidae), assassin bug, was collected from stems. Several individuals were collected at different stages of development. Members of family Reduviidae are predaceous on other insects (Borror et al 1992). Since this insect preys upon smaller insects such as aphids, scales, mites, etc., its presence may be an advantage to jackfruit trees and thus it is categorized as a beneficial insect in this study. Although pink waxy scale Cerolastes rubens, the jackfruit aphid Greenidea artocarpi (Westwood), and black citrus aphid Toxoptera aurantii (Fronsco Iombe) were reported on jackfruit trees in India (Butani 1979), none were found on jackfruit trees in South Florida. Presence of predators may partially contribute to lack of problem pests.

\section{Pollinators}

Euphoria sepulchralis (Coleoptera: Scarabaeidae), a flower beetle, was found visiting the male inflorescences. The beetle is oblong-oval, dark brown, bronzed, slightly shiny and reaches a length of 9-13 mm. Adults are usually found on flowers and feign death when touched (Dillon and Dillon 1961). Earlier studies have reported scarab beetles on male flowers of jackfruit in South Florida while none were seen on the female flowers (Campbell and McNaughton 1994). This flower beetle belongs to the subfamily

Cetoniinae. Members of this group are principally pollen feeders and are common on flowers. Many of them also occur under loose bark or in debris (Borror et al 1992). The larvae feed on organic matter in the soil and some damage plant roots (Borror et al 1992). Several adult beetles were usually found on a single male inflorescence of jackfruit either on the surface or inside the inflorescence feeding on floral tissues. Observed insects were 
on flowers usually in the late stages of floral development, which were beginning to rot. Beetles found on the inflorescences were observed for more than one hour and never seen visiting the female inflorescences. In order to identify these flower beetles as pollinators, visitation of flowers should be on a regular basis and should be a regular part of the daily life of the pollinator (Faegri and Van der Pij1 1971). This relationship between the flower beetles and jackfruit was not observed. An alternative mechanism of pollination would be 'insect assisted wind pollination' as suggested by Brantjes (1981) for Artocarpus altilis (breadfruit). The beetle feeding may release pollen from anthers, which is then carried by wind. He collected Trigona fulventris var. guianae from breadfruit trees in Brazil. These bees were collected only from the male inflorescences. This may be the case in jackfruit.

\section{Carpophilus dimidiatus (corn sap beetle) and Carpophilus tempestivus}

(Coleoptera: Nitidulidae) were also collected from the male inflorescences of jackfruit. They were both collected in the adult stage. The beetles were feeding on tissues both on surface and inside the inflorescences. They belong to family Nytidulidae, which includes sap and dried fruit beetles. Member of this family feed on decaying/fermenting plant tissues, many feed on fungal fruiting bodies or spores, some are pollen feeders, and some are predators (Stehr 1991). Carpophilus species are attracted to fermented fruits and some have been implicated in the transmission of pathogenic fungi. Carpophilus dimidiatus (corn sap beetle) is a primary pest of cultivated corn (Swan and Papp 1972). Both species were only seen on the rotting inflorescences, which questions their role in 
pollination. In order for them to play a role in pollination of jackfruit, they need to visit the male inflorescences at anthesis.

\section{Incidental}

Umbonia crassocornis (Amyot \& Serville) (Homoptera: Membracidae), the Thorn Bug, is green or greenish yellow with reddish and brownish lines and markings. Adults are about $12 \mathrm{~mm}$ in length and feed by sucking juices from tender twigs. Further damage occurs to twigs by egg-laying scars cut by the females. Several populations occur each year, mostly in the winter and early spring. However, they are sensitive to cold and hard freezes kill them (Maxwell 1990). Their known hosts are acacia, Australian pine, bottle brush, cat's claw, dwarf date palm, dwarf ponciana, jacaranda, Jerusalem thorn, lace flower, royal palm, royal poinciana, tamarind and wild tamarind (Chellman 1978). Populations on jackfruit were low, however, they were observed more than once on branches and leaves of the trees. They have been observed on other host plants in the area in greater populations and therefore were categorized as incidental insects on jackfruit.

Orocharis gryllodes (Orthoptera: Gryllidae), bush cricket, was collected from stems. This cricket has an elongate, slender body that is pale reddish-brown in color. The body reaches a length of $17-19 \mathrm{~mm}$. It is a West Indian species that was taken into the United States only in Southern Florida (Batchley 1920). Most members of this order are plant feeders. Some are important pests of cultivated plants, predators, scavengers, and a few are more or less omnivorous (Borror et al. 1992). Most species of the family 
Gryllidae overwinter as eggs laid generally in the ground or vegetation (Borror et al 1992). The specific role of this insect on jackfruit could be determined because these crickets were collected from stems.

\section{Pests}

Pachnaeus litus (German) (Coleoptera: Curculionidae), the Citrus root weevil, was collected from leaves. Larvae of the insects belonging to the subfamily Tanymecinae feed on a variety of herbaceous plants, shrubs, and trees (Borror et al 1992). This species is an important pest in the southeastern United States (Borror et al 1992).

Elaphidion mucronatum (Say) (Coleoptera: Cerambycidae) was collected from stems. This reddish brown to dark brown beetle reaches a length of $13-19 \mathrm{~mm}$. The antennae are longer than the body in males and about as long as the body in females (Arnett 1993). Adults lay eggs beneath bark scales of dead hardwoods. Larvae feed beneath the bark for the first year and enter sapwood in the second year (Dillon and Dillon 1961).

Nyssodrysina haldemani and Leptostylopsis terraecolor (Coleoptera: Cerambycidae) are dull colored long-horned beetles, collected from stems of jackfruit trees. Most members of this family are elongate and cylindrical with long antennae; eyes usually strongly notched or even completely divided; and many are brightly colored (Borror et al 1992). Most are wood boring in the larval stage and many are very 
destructive to shade, forest, and fruit trees and to freshly cut logs (Borror et al 1992). Adult Cerambycids, particularly the brightly colored ones, feed on flowers. Many, usually not brightly colored, are nocturnal and during the day may be found under bark or resting on trees or logs (Bororr et al 1992). Cerambycid beetles were seen during the day and during the night. All such beetles were collected in the adult stage. However, since they are known to bore into wood, they may cause a threat to the trees. Injury from such insect species could be serious. While the focus of this study was to collect potential pollinators, no special effort was done to search for larval stages of these wood boring insects.

Romalea microptera (Beauv.) (Orthoptera: Acrididae), the Lubber grasshopper, was found on leaves and stems. Some were observed feeding on leaves and some were undergoing ecdysis. The adults, which cannot fly, are yellowish with dark markings and have reddish areas on their wings, while young are black with yellow lines upon them (Maxwell 1990). They feed mostly on plants of the Lily family (Maxwell 1990). Although this species has been frequently seen on jackfruit trees, they were in greater numbers on other trees close by and should not be considered as serious pests.

Glyphodes sibillalis Wlk. (Lepidoptera: Pyralidae), a moth caterpillar, was collected from male inflorescenes. Unlike the flower beetle, this larva was feeding on the surface of newly emerged male inflorescences before pollen and anthers were produced on the surface. This species is rare in early summer, and somewhat more frequent later (Kimball 1965). However, it was observed on jackfruit during April and May. It is 
known to be more frequent in Miami during July and usually feeds on Morus rubra (Kimball 1965). Even with this species feeding on the inflorescences and destroying them, there has been no serious damage. It is important to note that jackfruit produce many male inflorescences and that might be a factor in showing no significant effect of this species. However, careful monitoring may be necessary in the future.

Destructive sampling of female inflorescence yielded no insects during both daytime and nighttime observations, while upon destructive sampling of male flowers in the late stages of floral development during daytime, Euphoria sepulchralis were collected along with Carpophilus dimidiatus and Carpophilus tempestivus. Both species of Carpophilus were also collected upon destructive sampling during the nighttime. In all destructive sampling, no other conspicuous insects were found. Further scrutiny of the male and female inflorescences may reveal other insects.

\section{Pollen dispersal by wind}

The microscope slides that were hung within the trees were collected and examined, and no jackfruit pollen grains were found on them. Few pollen grains of other unidentified species were collected on the slides, which raises questions about the use of this technique. A disadvantage of using these traps is that precipitation or heavy dew can wash pollen off slides or embed it in the substrate, making identification difficult (Kearns and Inouye 1993). Several other techniques such as Kramer-Collins 7-Day Drum Spore Sampler, Cascade Impactor, Rotorod samplers and others were suggested by Kearns and 
Inouye (1993) to use as a measure of pollen transfer by wind, but were not attempted in this study.

\section{Conclusions}

No insects were found visiting the female inflorescences of jackfruit. The only insects found on male inflorescences are Euphoria sepulchralis, Carpophilus dimidiatus and Carpophilus tempestivus. Euphoria sepulchralis are known to be found on a variety of flowers. Observations made in this study suggest that while flower beetles, Euphoria sepulchralis, are occasionally found on the male inflorescences of jackfruit, they are not present in sufficient numbers to account for full fruit set in this species. The role of these beetles in jackfruit pollination may be insect assisted wind-pollination. The beetles of the genus Carpophilus are attracted to the fermenting smell of the male inflorescences which questions the role they may have in pollination. Upon testing for wind pollination, we could not conclude that jackfruit pollen is transferred by wind, however there are other techniques that may be used to test for wind pollination. Future work that focuses on smaller insects may reveal some that develop within the flowers, however, this study found no such relationship.

Virtually no insect pests attack jackfruit in South Florida and control measures are not necessary (Campbell and McNaughton, 1994). However, until this research, there has been no scientific investigation of potential pests of jackfruit in South Florida. With the increased tree numbers in the area and solid block plants for commercial production, the potential exists for the development of new pests. We collected insects from various 
trees that may cause damage. The most important potential pests are the wood borers. Several shoot and bark borers have been reported on jackfruit trees in India, however they were different from the species collected in South Florida. If population density of the wood borers is sufficient, serious damage may occur. However, none of the insects collected pose any serious warranty control at this time. 


\section{Literature Cited}

Acedo, A. L. 1992. Jackfruit biology, production, use, and Philippine research.

Forestry/Fuelwood Research and Development (F/FRED), Arlington, VA.

Arnett, RH Jr. (1993). American Insects: A Handbook of the insects of America North of

Mexico. The Sandhill Crane Press, Inc. Gainesville, FL.

Blatchley, WS (1920). Orthoptera of Northeastern America. The Nature Publishing

Company, Indianapolis.

Borror, DJ, Triplehorn, CA and Johnson, NF (1992). An introduction to the study of insects. Sixth ed. Harcourt Brace \& Co., Orlando, FL.

Brantjes, NBM (1981). Nectar and the pollination of breadfruit Artocarpus altilis (Moraceae). Acta Bot. Neerl. 30(5/6): 345-352.

Butani, D. K. 1979. Insect pests of fruit crops and their control; jackfruit. Pesticides 13(11) pp. 36-40,44.

Campbell, R. J. and R. McNaughton. 1994. New jackfruit cultivars under trial in South Florida. Proc. Interamer. Soc. Trop. Hort. 38: 201-205.

Chellman, CW (1978). Pests and problems of South Florida trees and palms. Florida Department of Agriculture and Consumer Services, Division of Forestry. CRC. 1990. Philippine Agribusiness Factbook and Directory, 1989-1990, 67. Manila: Center for Research and Communication.

Dillon, ES and Dillon LS (1961). A Manual of Common Beetles of Eastern North America. Row, Peterson and Company. Evanston, Ill, Elmsford, NY.

Endress, PK (1994). Diversity and evolutionary biology of tropical flowers. Cambridge University Press, Cambridge. 
Faegri, K and Van der Pijl, L. (1971). The principles of pollination ecology. 2nd rev. ed. Pergamon Press, Oxford, New York.

Kearns, CA, Inouye DW (1993). Techniques for pollination biologists. University Press of Colorado, Niwot, Colo.

Kimball, CP (1965), Arthropods of Florida and neighboring land areas (Volume 1) Lepidoptera of Florida. Florida Department of Agriculture, Gainesville, FL. Maxwell, LS (1990). Florida Insects: Their habits and control. Lewis Maxwell, Tampa, FL.

Moncur, M. W. 1985. Floral Ontogeny of the jackfruit. Australian Journal of Botany 33:585-93.

Morton JF (1990). Under-Exploited Fruit-Vegetables Can Enhance the World Food Supply. Acta Horticulture, pp. 401-408

Primack RB (1985). Comparative Studies of Fruits in Wild and Cultivated Trees of Chempedak (Artocarpus integer) and terap (Artocarpus odoratissimus) in Sarawak, East Malaysia with Additional Information on the Reproductive Biology of the Moraceae in Southeast Asia. Malay, Nat. J. 39: 1-39.

Proctor, M, P Yeo and A Lack (1996). The Natural History of Pollination. Timber Press, Inc. Portland, Oregon.

Purseglove, JW (1968). Tropical Crops - Dicotyledons. Longman Scientific \& Technical, Essex, England pp. 384-386.

Samaddar, HN (1985). Jackfruit. In Bose, TK Fruits of India: Tropical and Subtropical. Calcutta: Naya Prokash, pp. 487-497.

Stehr, FW (1991). Immature insects (Volume 2). Kendall/Hunt Publishing Co., USA 
Swan, LA and Papp, CS. The common insects of North America. Harper and Row, Publishers, Inc., New York.

Soepadmo, E. (1991). Artocarpus heterophyllus Lamk. In Verheij EWM and Coronel RE ed. Plant Resources of South-East Asia. No. 2 Edible Fruits and Nuts. Pudoc Wageningen, pp. 96-91.

Sundararaj, DD and Ramanujam, K. (1953). Studies on the Floral Morphology of Jack Artocarpus heterophyllus Lamk. (Syn. A. integrifolius, L.f.) S. Indian Hortic. 1: $56-61$ 


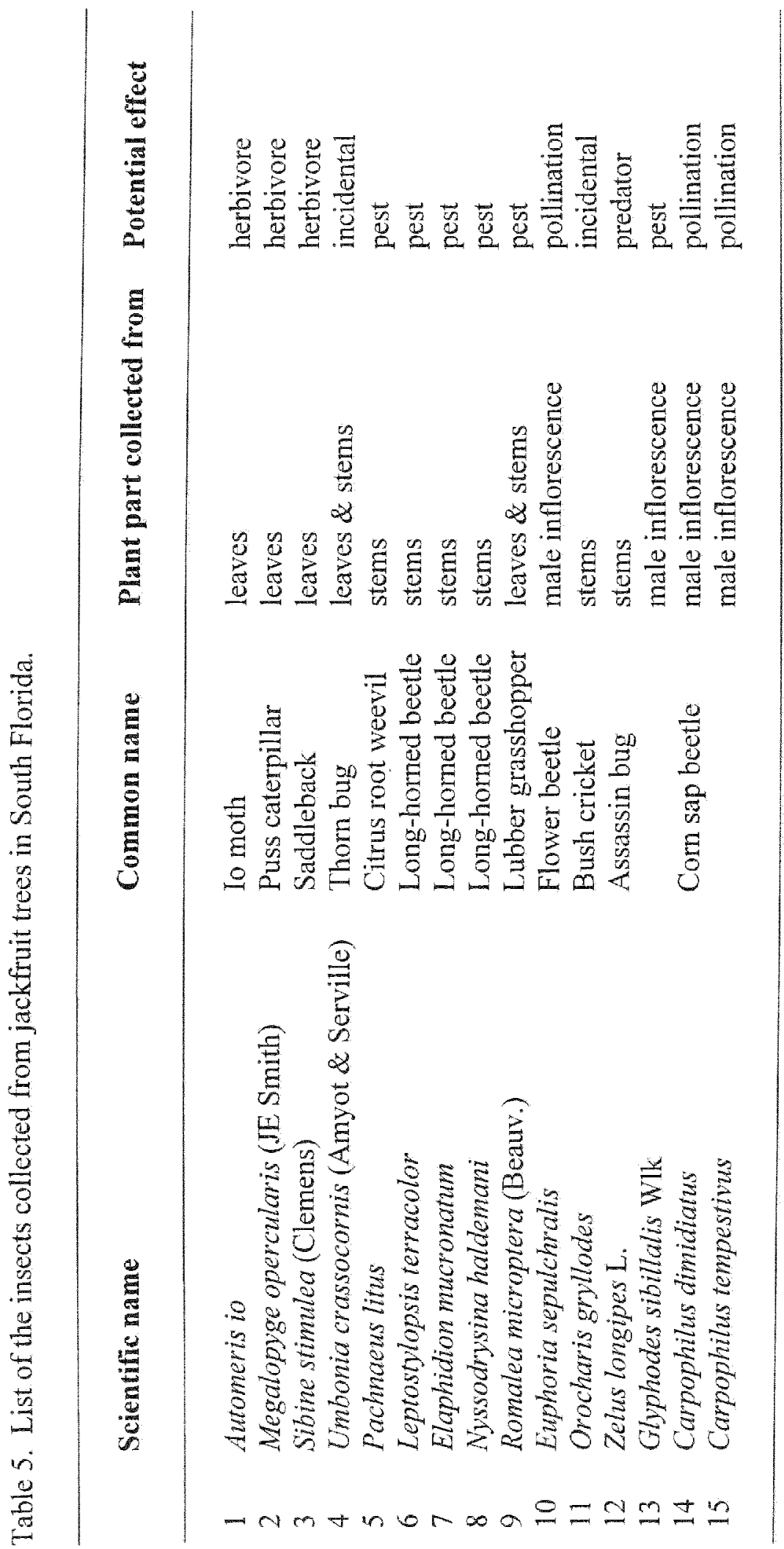

